\title{
Commentary
}

\section{Peptide Revolution: Genomics, Proteomics and Therapeutics}

\author{
T.K. Sawyer and M. Chorev ${ }^{1}$ \\ ARIAD Pharmaceuticals, Cambridge, and ${ }^{1}$ Beth Israel Deaconess Medical Center, \\ Harvard Institute of Medicine, Boston, MA, USA
}

\section{AN ITERATIVE REVOLUTION}

Peptide science has emerged as one of the most interdisciplinary fields for basic research, and it has integrated many technologies to advance drug discovery. Indeed, the identification and optimization of peptide analogs and first- and next-generation peptidomimetic and non-peptide ligands for various therapeutic targets have provided abundant opportunities to synthetic, computational, and biophysical chemists, biochemists, cell biologists, immunologists, pharmacologists, and biomaterials and drug delivery scientists (1-33). It's almost unimaginable now to realize that, only a few decades ago, the synthesis of a relatively simple peptide was not the generally straightforward automated task that exists today. On the other hand, contemporary peptide chemistry continues to push the limits of creating synthetic peptides of complex structure or large size. In particular, iterative achievements in peptide chemistry have progressed to the use of global or local cyclizations, novel amino acids or peptidomimetic building blocks, and the synthetic mimicry of post-translational modifications (e.g., glycosylaton, phosphoryation, and prenylation). Furthermore, current technology can incorporate more sophisticated conformation-inducing modifications that give rise to intermolecular complexes having protein-like structural and/or functional properties (24-40). Such achievements take into account significant improvements in synthesis (e.g., reagents and protecting groups) and purification technologies. Lastly, the development of novel homologs of peptides constructed using $\beta$ amino acids or $\mathrm{N}$-substituted Gly scaffolds has expanded the toolbox of synthetic building blocks as well as our fundamental understanding of peptide 3-D structure, metabolism, and molecular recognition (31-33).

Efforts to minimize the molecular complexity of large peptides ( $>30$ amino acids) to create novel synthetic peptidomimetics or non-peptides that mimic or block the biological properties of such peptides have met with some success, but the challenges and opportunities remain significant. "Smart" chemistry, which integrates both combinatorial libraries and 3-D structural insights from peptide ligands and/or their therapeutic targets (e.g., receptors, proteases, and signal transduction proteins), has resulted in the discovery of promising lead compounds having varying degrees of peptide, peptidomimetic, or non-peptide chemical nature $(1-4,6-18,32-44)$. However, there are a few examples that illustrate the successful transition of large peptides having non-contiguous amino acid sequences comprising the pharmacophore (i.e., key molecular recognition elements for therapeutic target binding and/or functional properties) to de novo designed peptidomimetics or non-peptides.

Peptide drug discovery seems relatively far advanced compared to current strategies focused on both existing and forthcoming therapeutic targets - the latter including those recently identified from the human genome $(45,46)$ as well as the genomes of other human pathogenic organisms (e.g., bacterial, fungal, and viral). In many cases, we may not yet know what the endogenous "ligand" (peptide, protein, or other molecule) is for a genetically implicated therapeutic target. Nevertheless, an iterative geno$\mathrm{mics} /$ proteomics/therapeutics revolution is ongoing and accelerating the process of target-ligand basic research and drug discovery (Figure 1). Such efforts will exploit peptide science in terms of molecular diversity and drug design to advance novel peptide, peptidomimetic, and non-peptide ligands. That is, peptide, peptidomimetic, and/or non-peptide ligands can be developed to fulfill the critical molecular recognition and functional properties involved with the activation, inhibition, association, or dissociation of therapeutic targets (i.e., singular or "multicomponent assemblies" as recognized for several receptors and signal transduction proteins).

Without question, the iterative revolution of peptide science will also be powerfully influenced by 3-D structure-guided drug discovery. These include a rapidly emerging worldwide "database" of X-ray and NMR structures providing high-resolution molecular maps of the therapeutic target (or surrogate target), including complexes thereof with peptides, peptidomimetics, and nonpeptides $(3,15-18,34,37,41,44,47,48)$. The Protein Data Bank is already growing at a rapid pace with new 3-D structures, high-throughput X-ray crystallization and NMR methods (49-53), and more powerful in silico drug design technologies (54-66). Further convergence of such structure-based drug design strategies with both emerging 


\section{Commentary}

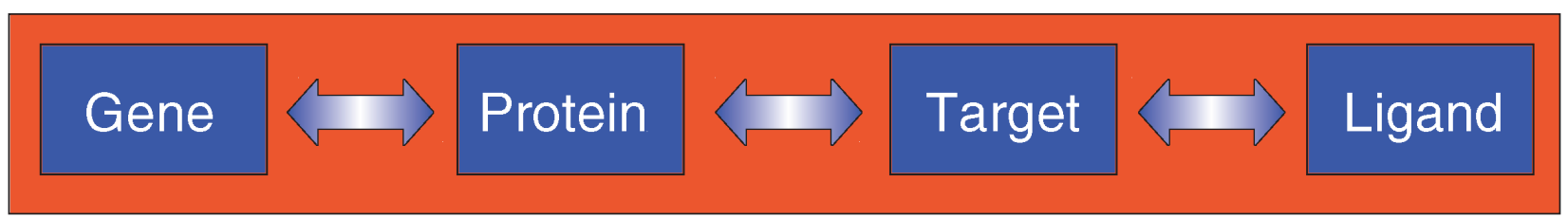

Figure 1. The iterative genomics/proteomics/therapeutics revolution and the potential role of peptide, peptidomimetic, and non-peptide ligands.

therapeutic targets and biological screening with synthetic libraries of chemically diverse ligands has been established $(2,9,12,33,40)$. Without question, peptide, peptidomimetic, and non-peptide ligands will play a critical role in this evolving paradigm of drug discovery.

\section{AN INTEGRATING REVOLUTION}

Milestones in peptide, peptidomimetic, and non-peptide ligand chemistry, biology, structure, and drug design have been achieved for several superclasses of therapeutic targets - namely, receptors, proteases, and signal transduction and gene regulatory proteins. Some examples of receptors for which key 3-D structural information and/or a novel ligand have been advanced include recent studies on $\mathrm{G}$ protein-coupled receptors $(14,18,33,36,42,75,76)$, integrin, growth factor receptors $(34,77-79)$, and cytokine and other immune-related receptors (80-83). Furthermore, some examples of proteases for which key 3-D structural information and/or a novel ligand have been advanced include recent studies on aspartyl proteases $(15,18,37,48,84,85)$, cysteinyl proteases $(86,87)$, serinyl proteases $(88,89)$, and metalloproteases $(90,91)$. Finally, some examples of signal transduction and gene regulatory proteins for which key 3-D structural information and/ or a novel ligand have been advanced include recent studies on protein transferase $(38,92)$, protein kinases $(93,94)$, protein phosphatases $(95,96)$, and several non-catalytic protein-protein interactions $(34,41,44,97-100)$.

\section{AN INSPIRED REVOLUTION}

The peptide revolution of the third millennium will be extraordinary in terms of both basic research and drug discovery. It will meet the challenge with inspiration from a legacy of achievement in chemistry, biology, structural studies, and drug design that have been pioneered by prominent scientists, including many Nobel Laureates, each of whom have contributed immensely both conceptually and experimentally to the interdisciplinary knowledge of today. The world of peptide science exists within various scientific societies, including the American Peptide Society, which provide international forums to disseminate new advances in basic research and drug discovery. In this regard, the Eighteenth American Peptide Symposium (to be held in Boston on July 19-23, 2003) will provide an inspiring forum to usher in this new era in peptide science as suggested by its theme "Peptide Revolution: Genomics, Proteomics, and Therapeutics."

\section{REFERENCES}

1.Ahn, J.A., N.A. Boyle, M.T. MacDonald, and K.D. Janda. 2002. Peptidomimetics and peptide backbone modifications. Mini Rev. Med. Chem. 2:463-473

2.Al-Obeidi, F.A., V.J. Hruby, and T.K. Sawyer. 1998. Peptide and peptidomimetic libraries: molecular diversity and drug design. Mol. Biotechnol. 9:205-223.

3.Bursavich, M.G. and D.H. Rich. 2002. Designing non-peptide peptidomimetics in the 21st century: inhibitors targeting conformational ensembles. J. Med. Chem. 31:541-558.

4.Chorev, M. and M. Goodman. 1995. Recent developments in retro 


\section{Commentary}

pepides and proteins - an ongoing topochemical exploration. Trends Biotechnol. 13:438-445.

5.Eguchi, M. and M. Kahn. 2002. Design, synthesis, and application of peptide secondary structure mimetics. Mini Rev. Med. Chem. 2:447-462.

6.Fairlie, D.P., G. Abbenante, and D.R. March. 1995. Macrocyclic peptidomimetics: forcing peptides into bioactive conformations. Curr. Med. Chem. 2:654-686.

7.Freidinger, R.M. 1999. Nonpeptidic ligands for peptide and protein receptors. Curr. Opin. Chem. Biol. 3:395-406.

8.Goodman, M. and S. Ro. 1994. Peptidomimetics for drug design, $p$. 803-861. In M.E. Wolff (Ed.), Medicinal Chemistry and Drug Design. vol. I. Principles of Drug Discovery. 5th ed. John Wiley \& Sons, New York.

9.Houghten, R.A. 2000. Parallel array and mixture-based synthetic combinatorial chemistry: tools for the next millennium. Annu. Rev. Pharmacol. Toxicol. 40:273-282.

10.Hruby, V.J., F.A. Al-Obeidi, and W. Kazmierski. 1990. Emerging approaches in the molecular design of receptor-selective peptide ligands. Biochem. J. 268:249-262.

11.Hruby, V.J. 2002. Designing peptide receptor agonists and antagonists. Nat. Rev. Drug Discov. 1:847-858.

12.Lam, K.S. and Renil, M. 2002. From combinatorial chemistry to chemical microarray. Curr. Opin. Chem. Biol. 6:353-358

13.Marshall, G.R. 1993. A hierarchial approach to peptidomimetic design. Tetrahedron 49:3547-3558.

14.Olson, G.L., D.R. Bolin, N.P. Bonner, M. Bos, C.M. Cook, D.C Fry, B.J. Graves, et al. 1993. Concepts and progress in the development of peptide mimetics. J. Med. Chem. 36:3039-3049.

15.Rich, D.H. 2002. Discovery of nonpeptide, peptidomimetic peptidase inhibitors that target alternate enzyme active site conformations. Biopolymers 66:115-125.

16.Ripka, A.S. and D.H. Rich. 1998. Peptidomimetic design. Curr Opin. Chem. Biol. 2:441-452.

17.Sawyer, T.K. 1999. Peptidomimetic and nonpeptide drug discovery: chemical nature and biological targets, p. 81-114. In R. Reid (Ed.) Drugs and the Pharmaceutical Sciences. vol. 101. Marcel Dekker, New York.

18.Sawyer, T.K. 1997. Peptidomimetic and nonpeptide drug discovery: impact of structure-based design, p. 559-634. In P. Veerapandian (Ed.), Structure-Based Drug Design: Diseases, Targets, Techniques and Developments. Marcel Dekker, New York.

19.Sundaram, R., N.K. Dakappagari, and P.T. Kaumaya. 2002. Synthetic peptides as cancer vaccines. Biopolymers 66:200-216.

20.Jackson, D.C., A.W. Purcell, C.J. Fitzmaurice, W. Zeng, and D.N. Hart. 2002. The central role played by peptides in the immune response and the design of peptide-based vaccines against infectious diseases and cancer. Curr. Drug Targets 3:175-196.

21.Burton, P.S., R.A. Conradi, N.F. Ho, A.R. Hilgers, and R.T. Borchardt. 1996. How structural features influence the biomembrane permeability of peptides. J. Pharm. Sci. 85:1336-1340.

22.LaVan, D.A., D.M. Lynn, and R. Langer. 2002. Moving smaller in drug discovery and delivery. Nat. Rev. Drug Discov. 1:77-84

23.Bernkop-Schnurch, A. and G. Walker. 2001. Multifunctional matrices for oral peptide delivery. Crit. Rev. Ther. Drug Carrier Syst. 18:459-501

24.Craik, D.J., S. Simonsen, and N.L. Daly. 2002. The cyclotides: novel macrocyclic peptides as scaffolds in drug design. Curr. Opin. Drug Discov. Develop. 5:251-260.

25.Micklatcher, C. and J. Chmielewski. 1999. Helical peptide and protein design. Curr. Opin. Chem. Biol. 3:724-729.

26.Liu, L.P. and C.M. Deber. 1998. Guidelines for membrane protein engineering derived from de novo designed model peptides. Biopolymers 47:41-62.

27.Annis, I., B. Hargittal, and G. Barany. 1997. Disulfide bone formation in peptides. Methods Enzymol. 289:198-221

28.Dawson, P.E. and S.B. Kent. 2000. Synthesis of native proteins by chemical ligation. Annu. Rev. Biochem. 69:923-960.

29.Sakakibara, S. 1995. Synthesis of large peptides in solution. Biopolymers 37:17-28

30.Sadler, K. and J.P. Tam. 2002. Peptide dendrimers: applications and synthesis. J. Biotechnol. 90:195-229.
31.Cheng, R.P., S.H. Gellman, and W.F. DeGrado. 2001. $\beta$-peptides: from structure to function. Chem. Rev. 101:3219-3232.

32.Steer, D.L., R.A. Lew, P. Perlmutter, A.I. Smith, and M.I Aguilar. 2002. $\beta$-amino acids: versatile peptidomimetics. Curr. Med. Chem. 9:811-822.

33.Figliozzi, G.M, R. Goldsmith, S.C. Ng, S.C. Banville, and R.N. Zuckermann. 1996. Synthesis of N-substituted glycine peptoid libraries. Methods Enzymol. 267:437-447.

34.Gadek, T.R. and J.B. Nicholas. 2003. Small molecule antagonists of proteins. Biochem. Pharmacol. 76:1-8.

35.Hirschmann, R., P.A. Sprengeler, T. Kawasaki, J.W. Leahy, W.C. Shakespeare, and A.B. Smith III. 1992. The first design and synthesis of a steroidal peptidomimetic. The potential value of peptidomimetics in elucidating the bioactive conformation of peptide ligands. J. Amer. Chem. Soc. 114:9699-9701.

36.Hirschmann, R., K.C. Nicolaou, S. Pietranico, J. Salvino, E.M. Leahy, P.A. Sprengeler, G. Furst, et al. 1992. Nonpeptidal peptidomimetics with $\beta$-D-glucose scaffolding. A partial somatostatin agonist bearing close structural relationship to a potent, selective substance P antagonist. J. Amer. Chem. Soc. 114:9217-9218.

37.Kempf, D. and H.L. Sham. 1996. HIV protease inhibitors. Curr Pharm. Design 2:225-246.

38.Qian, Y., S.M. Sebti, and A.D. Hamilton. 1997. Farnesyltranserase as a target for anticancer drug design. Biopolymers (Pept. Sci.) 43:25-41.

39.Roberts, N.A., J.A. Martin, D. Kinchington, A.V. Broadhurst, J.C. Craig, I.B. Duncan, S.A. Galpin, et al. 1990. Rational design of peptide-based HIV proteinase inhibitors. Science 248:358-361.

40.Rohrer, S.P., E.T. Birzin, R.T. Mosley, S.C. Berk, S.M. Hutchins, D.-M. Shen, Y. Xiong, et al. 1998. Rapid identification of subtypeselective agonists of the somatostatin receptor through combinatorial chemistry. Science 282:737-740.

41.Sawyer, T.K., R.S. Bohacek, D.C. Dalgarno, C.J. Eyermann, N. Kawahata, C.A. Metcalf, et al. 2002. Src homology-2 inhibitors: peptidomimetic and nonpeptide. Mini Rev. Med. Chem. 2:475-488.

42.Sebhat, I.K., M.J. Martin, Z. Ye, K. Barakat, R.T. Mosley, D.B. Johnston, R. Bakishi, et al. 2002. Design and pharmacology of N [(3R)-1,2,3,4-tetrahydroisoquinolinium-3-ylcarbonyl]-(1R)-1(4chlorobenzyl)-2-[4-(1H-1,2,4-triazol-1-ylmethyl)piperidin-1-yl]-2oxoethylamine (1), a potent, selective, melanocortin subtype-3 receptor agonist. J. Med. Chem. 45:489-4593.

43.Smith, A.B., S.D. Knight, P.A. Sprengler, and R. Hirschmann 1996. The design and synthesis of 2,5-linked pyrrolinones: a potential non-peptide peptidomimetic scaffold. Bioorg. Med. Chem. 4:1021-1034.

44.Shakespeare, W.C., M. Yang, R. Bohacek, F. Cerasoli, K. Stebbins, R. Sundaramoorthi, et al. 2000. Structure-based design of an osteoclast-selective, nonpeptide Src homology-2 inhibitor with in vivo antiresorptive activity. Proc. Natl. Acad. Sci. USA 15:93739378

45.International Human Genome Sequencing Consortium. 2001 Initial sequencing and analysis of the human genome. Nature 409:860-921.

46.Venter, C., M.D. Adams, E.W. Myers, P.W. Li, R.J. Mural, G.G Sutton, H.O. Smith, et al. The sequence of the human genome. Science $291: 1304-1351$

47.Dalgarno, D., C. Metcalf, W. Shakespeare, and T.K. Sawyer. 2000. Signal transduction drug discovery: targets, mechanisms, and structure-based design. Curr. Opin. Drug Disc. Dev. 3:549-564.

48.Cooper, J.B. 2002. Aspartic proteinases in disease: a structural perspective. Curr. Drug Targets 3:155-73.

49.Blundell, T.L., H. Jhotti, and C. Abell. 2002. High-throughput crystallography for lead discovery in drug design. Nat. Rev. Drug Discov. 1:45-54.

50.Diercks, T., M. Coles, and H. Kessler. 2001. Applications of NMR in drug discovery. Curr. Opin. Chem. Biol. 5:285-291.

51.Hajduk, P.J., R.P. Meadows, and S.W. Fesik. 1999. NMR-based screening in drug discovery. Q. Rev. Biophys. 32:211-240.

52.Nienaber, V.L., P.L. Richardson, V. Klighofer, J.J. Bouska, V.L. Giranda, and J. Greer. 2001. Discovering novel ligands for macromolecules using X-ray crystallographic screening. Nat. Biotechnol. 18:1105-1108 
53.Karle, I.L. 1996. Flexibility in peptide molecules and restraints imposed by hydrogen bonds, the Aib residue, and core inserts. Biopolymers. 40:157-180.

54.Antel. J. 1999. Integration of combinatorial chemistry and structure-based drug design. Curr. Opin. Drug Disc. Dev. 2:224-233.

55.Bohacek, R. and C. McMartin. 1997. Modern computational chemistry and drug discovery: structure-generating programs. Curr. Opin. Chem. Biol. 1:157-161.

56.Bohm, H.-J. and M. Stahl. 2000. Structure-based library design: molecular modeling merges with combinatorial chemistry. Curr. Opin. Chem. Biol. 4:283-286.

57.Davies, T.G., J.R.H. Tame, and R.E. Hubbard. 2001. Generating consistent sets of thermodynamic and structural data for analysis of protein-ligand interactions. Perspect. Drug Disc. Design. 20:29-42.

58.Joseph-McCarthy, D. 1999. Computational approaches to structure-based drug design. Pharmocol. Ther. 84:179-191.

59.Klebe, G. 2000. Recent developments in structure-based drug design. J. Mol. Med. 78:269-281.

60.Langer, T. and R.D. Hoffmann. 2001. Virtual screening: an effective tool for lead structure discovery. Curr. Pharm. Des. 7:509-527.

61.Li., J. and B. Robson. 2000. Bioinformatics and computational chemistry in molecular design: recent advances and their applications. Drugs Pharm. Sci. (Peptide and Protein Drug Analysis) 101:285-307.

62.Norin, M. and M. Sundstrom. 2001. Protein models in drug discovery. Curr. Opin. Drug Discov. Develop. 4:284-290.

63.Mason, J.S., A.C. Good, and E.J. Martin. 2001. 3-D pharmacophores in drug discovery. Curr. Pharm. Des. 7:567-597.

64.Muege, I. and Y.C. Martin. 1999. A general and fast scoring function for protein-ligand interactions: a simplified potential approach. J. Med. Chem. 42:791-804

65.Murcko, M.A., P.R. Caron, and P.S. Charifson. 1999. Structurebased drug design. Annu. Rep. Med. Chem. 34:297-306.

66.Roche, O., R. Kiyama, and C.L. Brooks III. 2001. Ligand-protein database: linking protein-ligand complex structures to binding data. J. Med. Chem. 44:3592-3598.

67.Martin, A.B. and P.G. Schultz. 1999. Opportunities and the interface of chemistry and biology. Trends Cell Biol. 9:M24-28.

68.Sisido, M. and T. Hohsaka. 2001. Introduction of specialty functions by the position-specific incorporation of non-natural amino acids into proteins through four-base codon/anticodon pairs. Appl. Microbiol. Biotechnol. 57:274-281.

69.Caron, P.R., M.D. Mullican, R.D. Marshal, K.P. Wilson, M.S. Su, and M.A. Murcko. 2001. Chemogenomic approaches in drug discovery. Curr. Opin. Chem. Biol. 5:464-270.

70.Zambrowicz, B.P. and A.T. Sands. 2003. Knockout model the 100 best-selling drugs - will they model the next 100? Nat. Drug Discov. 2:38-51.

71.Olsson, T. and T.I. Oprea. 2001. Cheminformatics: a tool for decision-makers in drug discovery. Curr. Opin. Drug Disc. Dev. 4: 308-313.

72.Lipinski, C.A., F. Lombardo, B.W. Dominy, and P.J. Feeney. 2001. Experimental and computational approaches to estimate solubility and permeability in drug discovery and development settings. Adv. Drug Deliv. Rev. 46:3-26.

73.Ulrich, R. and S.H. Friend. 2002. Toxicogenomics and drug discovery: will new technologies help us produce better drugs? Nat. Rev. Drug Discov. 1:84-88.

74.Van de Waterbeemd, H, D.A. Smith, K. Beaumont, and D.K. Walker. 2001. Property-based design: optimization of drug absorption and pharmacokinetics. J. Med. Chem. 44:1313-1333.

75.Marshall, G.R. 2001. Peptide interactions with G-protein coupled receptors. Biopolymers. 60:246-277.

76.Filipek, S., D.C. Teller, K. Palczewski, and R. Stenkamp. 2003 The crystallographic model of rhodopsin and its use in studies of other G protein-coupled receptors. Annu. Rev. Biophys. Biomol. Struct. Feb. 5 Published online.

77.Weismann, C. and A.M. De Vos. 1999. Putting two and two together: crystal structure of the FGF-receptor complex. Structure 7:R251-R255.

78.Ogiso, H., R. Ishitani, O. Nureki, S. Fukai, M. Yamanaka, J.H. Kim, K. Saito, A. Sakamoto, et al. 2002. Crystal structure of the complex of human epidermal growth factor and receptor extracellular domains. Cell 110:775-787.

79.Xiong, J.-P., T. Stehle, B. Diefenbach, R. Zhang, R. Dunker, D.L. Scott, et al. 2001. Crystal structure of the extracellular segment of integrin $\alpha v \beta_{3}$. Science 296:151-155.

80.Gadek, T.R., D.J. Burdick, R.S. McDowell, M.S. Stanley, J.C. Marsters, Jr., K.J. Paris, et al. 2002. Generation of an LFA-1 antagonist by the transfer of the ICAM-1 immunoregulatory eptitope to a small molecule. Science 295:1086-1089.

81.Szakonyi, G., J.M. Guthridge, D. Li, K. Young, V.M. Holers, and X.S Chen. 2001. Structure of complement receptor 2 in complex with its C3d ligand. Science 292:1725-1728.

82.Chow, D.-C., H.-I. He, A.L Snow, S. Rose-John, and K.C. Garcia. 2001. Structure of an extracellular gp130 cytokine receptor signaling complex. Science 291:2150-2155.

83.Reinherz, E.L., K. Tan, L. Tang, P. Kern, J.-H. Liu, R.E. Hussey, et al. 1999. The crystal structure of a T cell receptor in complex with peptide and MHC class II. Science 286:1913-1921.

84.Roggo, S. 2002. Inhibition of BACE, a promising approach to Alzheimer's disease therapy. Curr. Topics Med. Chem. 2:359-370.

85.Bowman, M.J. and J. Chmielewski. 2002. Novel strategies for targeting the dimerization interface of HIV protease with crosslinked interfacial peptides. Biopolymers 66:126-133.

86.Yamashita, D.S. and R.A. Dodds. 2000. Cathepsin K and the design of inhibitors of cathepsin K. Curr. Pharm. Design. 6:1-24.

87.Concha, N.O. and S.S. Abdel-Meguid. 2002. Controlling apoptosis by inhibition of caspases. Curr. Med. Chem. 9:73-726.

88.Quan, M.L. and R.R. Wexler. 2001. The design and synthesis of noncovalent Factor Xa inhibitors. Curr.Topics Med. Chem. 1:137149

89.Maiganan, S. and V. Mikol. 2001. The use of 3D structural data in the design of specific Factor Xa inhibitors. Curr. Topics Med. Chem. 1:161-174.

90.Skiles, J.W., N.C. Gonnella, and A.Y. Jeng. 2001. The design, structure and therapeutic application of matrix metalloproteinase inhibitors. Curr. Med. Chem. 8:425-474.

91.Lauer-Fields, J.L., D. Juska, and G.B. Fields. 2002. Matrix metalloproteinases and collogen catabolism. Biopolymers. 66:19-32.

92.Singh, S.B. and R.B. Lingham. 2002. Current progress on farnesyl protein transferase inhibitors. Curr. Opin. Drug Discov. Develop. 5:225-244.

93.Songyang, Z. and LC Cantley. 1995. Recognition and specificity in protein tyrosine kinase-mediated signaling. Trends Biochem. Sci. 20:471-475.

94.Alfaro-Lopez, J., W. Yuan, B.C. Phan, J. Kamath, Q. Lou, K.S. Lam, and V.J. Hruby. 1998. Discovery of a novel series of potent and selective substrate-based inhibitors of pp60c-src protein tyrosine kinase: conformational and topographical constraints in peptide design. J. Med. Chem. 18:2252-2260.

95.Burke, Jr., T.R., Z.J. Yao, D.G. Liu, J. Voigt, and Y. Gao. 2001 Phosphoryltyrosyl mimetics in the design of peptide-based signal transduction inhibitors. Biopolymers. 60:32-44.

96.Zhang, Y.Z. 2001. Protein tyrosine phosphatases: prospects for therapeutics. Curr. Opin. Chem. Biol. 5:416-423.

97.Huang Z. 2000. Bcl-2 family proteins as targets for anticancer drug design. Oncogene 19:6627-6631.

98.Blundell, T.L. D.F. Burke, D. Chirgadze, V. Dhanaraj, M. Hyvonen, C.A. Innis, E. Parisini, L. Pellegrini, et al. 2000. Protein-protein interactions in receptor activation and intracellular sig naling. Biol. Chem. 381:955-959.

99.DeLano, W.L., M.H. Ultsch, A.M. deVos, and J.A. Wells. 2000 Convergent solutions to binding at a protein-protein interface. Science 287:1279-1283.

100.Guo, Z., D. Zhou, and P.G. Schultz. 2000. Designing small-molecule switches for protein-protein interactions. Science 288:20422045.

Address correspondence to Dr. Tomi K. Sawyer, ARIAD Pharmaceuticals, Cambridge, MA, USA. e-mail: tomi.sawyer@ariad.com 